\title{
Expression of HIF-1 $\alpha$ and P-gp in non-small cell lung cancer and the relationship with HPV infection
}

\author{
YIMIN LU ${ }^{1}$, LE-QUN YU ${ }^{1}$, LIXIA ZHU ${ }^{2}$, NIAN ZHAO ${ }^{1}$, XING-JU ZHOU ${ }^{1}$ and XUDONG LU ${ }^{1}$ \\ Departments of ${ }^{1}$ Pneumology, and ${ }^{2}$ Gynecology and Obstetrics, The First People's Hospital of Kunshan, \\ Jiangsu University, Kunshan, Jiangsu 215300, P.R. China
}

Received January 29, 2016; Accepted June 17, 2016

DOI: $10.3892 / \mathrm{ol} .2016 .4751$

\begin{abstract}
The aim of the study was to study the expression of hypoxia-inducible factor- $1 \alpha(\mathrm{HIF}-1 \alpha)$ and P-glycoprotein (P-gp) and analyze its correlation with human papillomavirus (HPV) infection. From January, 2012 to May, 2014, 72 cases of non-small cell lung cancer (NSCLC) pathologic tissue samples were selected from the study group. Fifty-four lung benign lesions were selected to serve as the control group. HIF-1 $\alpha$ and P-gp expression levels were detected using immunohistochemistry. PCR was used to detect the expression of HPV genome employing specific primers for HPV 16 and 18 types. The results showed that there was 47.2 and $63.9 \%$ positive HIF-1 $\alpha$ and P-gp expression in the study group. No P-gp or HIF-1 $\alpha$ expression was detected in the control group. The results established a positive correlation between the expression of HIF-1 $\alpha$ and P-gp. In the study group, the expression and differentiation degree of HIF-1 $\alpha$ was related to lymphatic metastasis. The HIF-1 $\alpha$ expression in the well-differentiated samples was lower than that in the moderate or poorly differentiated samples. HIF-1 $\alpha$ expression in patients with lymphatic metastasis was higher than in patients without metastasis. The expression rate of $\mathrm{P}-\mathrm{gp}$ in adenocarcinoma was higher than that in squamous carcinoma. The detection rate of HPV DNA was 45.83 and $3.70 \%$ in the study and control groups, respectively. The HPV infection and differentiation degree had relevance to lymphatic metastasis in the study group. The HPV DNA detection rate in the well-differentiated samples was lower than that in the moderate or poorly differentiated samples. The HPV DNA detection rate in patients with lymphatic metastasis was higher than that in patients with no lymphatic metastasis. There was a close link between HIF-1 $\alpha$, P-gp expression and NSCLC occurrence, and the development of
\end{abstract}

Correspondence to: Dr Yimin Lu, Department of Pneumology, The First People's Hospital of Kunshan, Jiangsu University, No. 91 Qianjinxi Road, Kunshan, Jiangsu 215300, P.R. China E-mail: gjt5372@163.com

Key words: non-small cell lung cancer, hypoxia-inducible factor-1 $\alpha$, P-glycoprotein, human papillomavirus multidrug resistance. In conclusion, the detection of HIF-1 $\alpha$ and $\mathrm{P}$-gp expression can effectively predict drug resistance during chemotherapy in NSCLC, and these proteins can be used in drug prognosis.

\section{Introduction}

Hypoxia-inducible factor 1 (HIF-1) is a transcription factor and HIF-1 $\alpha$ overexpression has been reported in various tumors, such as breast and lung cancer (1-3). Previous findings revealed that multidrug resistance (MDR) mediated by P-glycoprotein (P-gp) existed universally in human tumor tissues, particularly in non-small cell lung cancer (NSCLC) $(4,5)$.

Human papillomavirus (HPV) is a DNA virus infecting humans and animals effectively and can cause hyperplastic lesions. Recent findings showed that lung cancer patients were also carrying HPV infection, especially HPV 16 and 18 (6-8). The correlation between HIF- $1 \alpha$ and P-gp in lung cancer and HPV infection is a topic that needs more research.

The aim of the present study was to analyze the relevance of NSCLC occurrence and development with HIF-1 $\alpha$ and P-gp expression. Additionally, we examined the correlation with HPV infection.

\section{Materials and methods}

Objects. From January 2012 to May 2014, 72 cases of NSCLC pathologic tissue samples were selected from the study group. The tissues collected from 52 men and 20 women served as the study group. In addition, 54 samples of lung benign lesions were selected to serve as the control group.

In the study group there were 48 cases of squamous carcinoma and 24 cases of adenocarcinoma. Of these, there were 18 cases of high differentiation, 28 cases of moderate differentiation, 26 cases of poor differentiation, 24 cases with lymph node metastasis, 48 patients with no lymph node metastasis, 46 cases with a smoking history, and 26 cases without smoking history. The control group included, 18 cases of pulmonary tuberculosis, 13 cases of inflammatory pseudo-tumor samples, 12 cases of sclerosing hemangioma samples, 7 cases of pulmonary bullae samples, and 4 cases of bronchiectasis samples. A part of each sample was preserved at $-20^{\circ} \mathrm{C}$, and the remaining samples were fixed with neutral formalin and embedded in paraffin. 
Written informed consent was obtained from all the patients. The study was approved by the Medical Ethics Committee of The First People's Hospital of Kunsan, Jiangsu University (Jiangsu, China).

\section{Detection of HPV DNA with PCR}

Primers. Two pairs of specific primers were designed for HPV types 16 and 18. The HPV 16E6 strands were, sense: 5'-CTG CAAGCAACAGTTACTGCGACG-3' and antisense, 5'-CAT ACATCGACCGGTCCACC-3', with a length of $315 \mathrm{bp}$. The HPV 18E7 strands were: sense, 5'-GAGCCGAACCACAAC GTCAC-3' and antisense, 5'-GGATGCACACCACGGAC ACA-3', with a length of $152 \mathrm{bp}$.

DNA extraction. A proper amount (10 g) of the frozen tissues was used to make single cell suspension by adding extraction buffer. Suspension was placed in a boiling water bath and after $10 \mathrm{~min}$, proteinase $\mathrm{K}$ was added for digestion. After the single cell suspension was obtained, it was cooled to $18^{\circ} \mathrm{C}$. Phenol chloroform and isoamyl alcohol was used for DNA extraction. Cold ethanol (100\%) was used for precipitation and $70 \%$ cold ethanol for rinsing. TE buffer $(10 \mathrm{mmol} / \mathrm{l}$ Tris- $\mathrm{HCl}, 1 \mathrm{mmol} / \mathrm{l}$ EDTA, pH 8.0) was used. The obtained DNA was kept at $4^{\circ} \mathrm{C}(3)$.

PCR amplification reaction and conditions. The PCR amplification reaction was determined using, each $25 \mu \mathrm{l}$ in the system contained $2.5 \mu 110 \mathrm{X}$ buffer, each $20 \mathrm{pmol} /$ primer with $0.5 \mu 1$, $1 \mu \mathrm{l}$ Taq enzyme ( $1 \mathrm{U} / \mathrm{l}), 0.5 \mu \mathrm{l}$ dNTPs, $16.5 \mu 1$ deionized water, $1.5 \mu \mathrm{l} \mathrm{Mg}^{2+}$ and $2 \mu \mathrm{l}$ DNA template. The amplification conditions were: Initial denaturation at $94^{\circ} \mathrm{C}(5 \mathrm{~min})$, followed by cycles of $94^{\circ} \mathrm{C}$ for $45 \mathrm{sec}, 55^{\circ} \mathrm{C}$ for $45 \mathrm{sec}$ and $72^{\circ} \mathrm{C}$ for $45 \mathrm{sec}$. Thirty cycles were used and extension was realized at $72^{\circ} \mathrm{C}$ for $8 \mathrm{~min}$. For the negative control group PCR without template was performed, and for the positive control SiHa and HeLa cell lines were used. The PCR products were subjected to electrophoresis under $80 \mathrm{~V}$ for $40 \mathrm{~min}$ using $1.5 \%$ agarose gel with ethidium bromide. The gel was examined under a UV transilluminator (9).

Immunohistochemical detection of the expression of HIF-1a and P-gp

Reagents and methods. HIF-1 $\alpha$ antibody, P-gp antibody and universal SP kit were purchased from Beyotime Biotech., Shanghai, China. Experimental operating was in accordance with the procedure described previously (10). Diluted concentration of primary antibodies (mouse anti-human monoclonal antibody against HIF-1 $\alpha$, catalog no. AH339; mouse antihuman monoclonal antibody against HIF- $1 \alpha$, catalog no. AH746) was 1:100. In negative control group, the primary antibody was replaced with PBS.

Reference standard. In the HIF-1 $\alpha$-positive standard sample, the nucleus had brown or brownish yellow particles and in the P-gp-positive standard sample, the cytoplasm or cell membrane had brown or brownish yellow particles. The staining results were evaluated by two experienced physicians according to the semi-quantitative scoring system (10). Each sample case was observed under high magnification (x400) with five randomly selected fields, and 200 cells were counted in each field.
Table I. Correlation between HIF-1 $\alpha$ and P-gp in NSCLC.

\begin{tabular}{lcrcc}
\hline & \multicolumn{2}{c}{ P-gp } & & \\
\cline { 2 - 3 } HIF-1 $\alpha$ & + & - & $\chi^{2}$ & P-value \\
\hline+ & 25 & 9 & 3.595 & 0.017 \\
- & 21 & 17 & & \\
\hline
\end{tabular}

HIF-1 $\alpha$, hypoxia-inducible factor-1 $\alpha$; P-gp, P-glycoprotein; NSCLC, non-small cell lung cancer.

The average value was calculated and the semi-quantitative scoring method was used to evaluate the results using the following scale: negative was considered 0 point; $<25 \%$ was 1 point; $25-75 \%$ was 2 points; and $>75 \%$ was 3 points. The positive intensity standard was: light yellow for weak expression (1 point), brown yellow for moderate intensity expression ( 2 points), and brown yellow for strong expression ( 3 points). The multiplication of two integral results was scored as: negative (-) was 0-1 point, weak positive ( $( \pm)$ was 2-3 points, moderate positive (+) was $4-6$ points, and strong positive $(++)$ was 7-9 points.

Statistical analysis. SPSS 20.0 (SPSS Inc., Chicago, IL, USA) was used for statistical analysis. The counting data are presented as a ratio, and the $\chi^{2}$ test was used for comparisons among data. The correlation between parameters was detected with the Spearman's rank correlation analysis. $\mathrm{P} \leq 0.05$ was considered to indicate a statistically significant difference.

\section{Results}

Correlation between HIF-l $\alpha$ and P-gp. In the study group, HIF-1 $\alpha$ positive expression was mainly observed in the nucleus, and the positive expression rate was $47.2 \%$ (34/72). In the control group, benign lung lesions had no positive expression and differences were statistically significant $\left(\chi^{2}=34.924, \mathrm{P}<0.05\right)$. A positive expression of $\mathrm{P}$-gp mainly existed in the cytoplasm or cell membrane and the positive expression rate was $63.9 \%$ (46/72), while there was no positive expression of $\mathrm{P}$-gp in the control group. Differences were statistically significant $\left(\chi^{2}=54.338, P<0.05\right)$. In patients with HIF-1-positive expression, we detected significantly higher P-gp-positive expression rate compared to that in patients with a negative HIF-1 $\alpha$ expression. The data were positively correlated $(\mathrm{r}=0.348, \mathrm{P}=0.025<0.05)$ (Table I).

Relationship between HIF-1 $\alpha$ and P-gp expression and clinical characteristics. Our results showed that in the study group, the HIF-1 $\alpha$ expression was independent of gender, age, smoking and tissue typing. However, the expression was correlated with the differentiation degree and lymph node metastasis. HIF-1 $\alpha$ expression in highly differentiated samples was considerably lower than that in the moderate or poorly differentiated samples and the difference was statistically significant $(\mathrm{P}<0.05)$. Additionally, HIF-1 $\alpha$ expression in patients with lymph node metastasis was significantly higher 
Table II. Association between HIF-1 $\alpha$ and P-gp expression and clinical characteristics.

\begin{tabular}{|c|c|c|c|c|c|c|c|c|c|}
\hline \multirow[b]{2}{*}{ Indexes } & \multirow[b]{2}{*}{ Cases } & \multicolumn{4}{|c|}{ HIF-1 $\alpha$} & \multicolumn{4}{|c|}{ P-gp } \\
\hline & & + & - & $\chi^{2}$ & P-value & + & - & $\chi^{2}$ & P-value \\
\hline \multicolumn{10}{|l|}{ Gender } \\
\hline Male & 52 & $25(48.07)$ & 27 (51.93) & 1.178 & 0.182 & $34(65.38)$ & $18(32.62)$ & 0.182 & 0.670 \\
\hline Female & 20 & $19(63.33)$ & $11(36.67)$ & & & $12(60.00)$ & $8(40.00)$ & & \\
\hline \multicolumn{10}{|l|}{ Age (years) } \\
\hline$<50$ & 27 & $12(44.44)$ & $15(55.56)$ & 0.049 & 0.826 & $15(55.56)$ & $12(44.44)$ & 1.300 & 0.254 \\
\hline$\geq 50$ & 45 & $24(47.06)$ & $21(52.94)$ & & & $31(68.89)$ & $14(31.11)$ & & \\
\hline \multicolumn{10}{|l|}{ Smoking } \\
\hline Yes & 46 & $26(56.52)$ & $20(43.43)$ & 1.129 & 0.288 & $30(65.22)$ & $16(34.78)$ & 0.097 & 0.755 \\
\hline No & 26 & $18(69.23)$ & $8(30.74)$ & & & $16(61.54)$ & $10(38.46)$ & & \\
\hline \multicolumn{10}{|l|}{ Histological type } \\
\hline Adenocarcinoma & 24 & $16(66.67)$ & $8(33.33)$ & 2.309 & 0.129 & $22(91.67)$ & $2(8.33)$ & 12.040 & 0.001 \\
\hline Squamous carcinoma & 48 & $28(48.28)$ & $30(51.72)$ & & & $24(50.00)$ & $24(50.00)$ & & \\
\hline \multicolumn{10}{|l|}{ Differentiation degree } \\
\hline Well & 18 & $4(22.22)$ & 14 (77.78) & 6.019 & 0.014 & $11(55.00)$ & $9(45.00)$ & 0.598 & 0.439 \\
\hline Moderate/poor & 54 & $30(55.56)$ & $24(44.44)$ & & & $35(64.81)$ & $19(35.19)$ & & \\
\hline \multicolumn{10}{|l|}{ Lymph node metastasis } \\
\hline Yes & 24 & $17(70.83)$ & 7 (29.17) & 6.250 & 0.012 & $18(75.00)$ & $6(25.00)$ & 1.926 & 0.165 \\
\hline No & 48 & $19(39.58)$ & $29(60.42)$ & & & $28(58.33)$ & $20(41.67)$ & & \\
\hline
\end{tabular}

HIF-1 $\alpha$, hypoxia-inducible factor-1 $\alpha$; P-gp, P-glycoprotein.

than that in those without lymph node metastasis and the difference was statistically significant $(\mathrm{P}<0.05)$. A positive expression of P-gp the in study group was not correlated with gender, age, smoking, differentiation degree or lymph node metastasis. However, it was related to histological type. We observed a significantly higher P-gp expression rate in adenocarcinoma compared with that in squamous carcinoma and the difference was statistically significant $(\mathrm{P}<0.05)$ (Table II).

PCR detection of HPV DNA and its association with clinical characteristics. In the study group, the detection rate for the HPV DNA was $45.83 \%$ (33/72) while this rate for the control group was only $3.70 \%(2 / 54)$. Differences were statistically significant $\left(\chi^{2}=27.30, \mathrm{P}<0.05\right)$. We detected 14 cases of HPV 16 and 19 cases of HPV 18. HPV infection was not associated with gender, age, smoking or histological typing, it was only associated with differentiation degree and lymph node metastasis in the study group. The HPV DNA detection rate in the well-differentiated samples was lower than that in the moderate and poorly differentiated samples and differences were statistically significant $(\mathrm{P}<0.05)$. The HPV DNA detection rate in patients with lymph node metastasis was higher than those without lymph node metastasis and the difference was statistically significant $(\mathrm{P}<0.05)$ (Table III).

Correlation between HIF-l $\alpha$ and P-gp expression and HPV infection. The HIF-1 $\alpha$-positive expression rate in the HPV DNA-positive samples was $51.23 \%$, while in the negative samples it was $48.77 \%$. The difference was not statistically significant $(\mathrm{P}>0.05)$. The positive expression rate of $\mathrm{P}-\mathrm{gp}$ in HPV DNA was $61.23 \%$ in the positive samples, and $58.97 \%$, in the negative samples. However, the difference was not statistically significant $(\mathrm{P}>0.05)$.

\section{Discussion}

HIF-1 is a heterodimer composed of $\alpha$ and $\beta$ subunits. HIF-1 $\alpha$ is mainly regulated by hypoxia, which is one of the characteristics of internal environment in solid tumors. Results from previous studies (11) showed that the HIF-1 $\alpha$ level significantly increased in the cell nucleus under hypoxia. It was shown that HIF-1 $\alpha$ played an important role in the regulation of many downstream genes that were involved in maintaining the process of tumor blood vessel formation and promoting tumor development. During the course of tumor growth, the formation of some related factors may result in a hypoxic environment, leading to malignant tumor growth, invasion and metastasis, which may create a vicious cycle (12).

The results showed that the positive expression rate of HIF- $1 \alpha$ in the study group was $47.2 \%$, while there was no positive expression in the control group. These findings showed that HIF-1 $\alpha$ was closely associated with the occurrence and development of NSCLC. We showed that the degree of histological differentiation and lymph node metastasis were closely associated with HIF-1 $\alpha$ expression. HIF-1 $\alpha$ regulated its downstream gene, $V E G F$, and induced lymphangiogenesis. COX-2 upregulation may lead to the enhancement of adhesion ability of tumor cells to matrix. It was shown that 
Table III. Association between HPV and clinical characteristics.

HPV DNA

\begin{tabular}{|c|c|c|c|c|c|}
\hline \multirow[b]{2}{*}{ Indexes } & \multirow[b]{2}{*}{ Cases } & & & & \\
\hline & & + & - & $\chi^{2}$ & P-value \\
\hline \multicolumn{6}{|l|}{ Gender } \\
\hline Male & 52 & $23(44.23)$ & $29(55.77)$ & \multirow[t]{2}{*}{0.194} & \multirow[t]{2}{*}{0.660} \\
\hline Female & 20 & $10(50.00)$ & $10(50.00)$ & & \\
\hline \multicolumn{6}{|l|}{ Age (years) } \\
\hline$<50$ & 27 & $11(40.74)$ & $16(59.26)$ & \multirow[t]{2}{*}{0.451} & \multirow[t]{2}{*}{0.502} \\
\hline$\geq 50$ & 45 & $22(48.89)$ & $23(51.11)$ & & \\
\hline \multicolumn{6}{|l|}{ Smoking } \\
\hline Yes & 46 & $21(45.65)$ & $25(54.35)$ & \multirow[t]{2}{*}{0.002} & \multirow[t]{2}{*}{0.967} \\
\hline No & 26 & $12(46.15)$ & $14(53.85)$ & & \\
\hline \multicolumn{6}{|l|}{ Histological type } \\
\hline Adenocarcinoma & 24 & $10(41.67)$ & $14(58.33)$ & \multirow[t]{2}{*}{0.252} & \multirow[t]{2}{*}{0.616} \\
\hline Squamous carcinoma & 48 & $23(47.92)$ & $25(52.08)$ & & \\
\hline \multicolumn{6}{|l|}{ Differentiation degree } \\
\hline Well & 18 & $4(22.22)$ & $14(77.78)$ & \multirow[t]{2}{*}{4.249} & \multirow[t]{2}{*}{0.039} \\
\hline Moderate/poor & 54 & $27(50.00)$ & $27(50.00)$ & & \\
\hline \multicolumn{6}{|l|}{ Lymph node metastasis } \\
\hline Yes & 24 & $15(62.50)$ & $9(37.50)$ & \multirow[t]{2}{*}{4.028} & \multirow[t]{2}{*}{0.045} \\
\hline No & 48 & $18(37.50)$ & $30(62.50)$ & & \\
\hline
\end{tabular}

HPV, human papillomavirus.

the E-cadherin protein expression level was decreased and resulted in the flexible metastasis of tumor cells. The results obtained from previous studies were consistent with our results (13). The results showed that a positive expression of HIF-1 $\alpha$ in the well-differentiated tumors was lower than that in the moderate and poorly differentiated tumors. We hypothesized that in lower degrees of tumor differentiation, the level of hypoxia was more serious, which caused an increase in HIF-1 $\alpha$-positive expression.

$\mathrm{P}$-gp is a drug efflux pump through which chemotherapy drugs are discharged. It was revealed that due to P-gp action, the intracellular concentration of chemotherapy drugs were ablet to decrease and drug resistance may occur (14-16). MDR mediated by $\mathrm{P}$-gp was found in various human tumors. Our results showed that while the $\mathrm{P}$-gp positive expression rate in the control group was zero, the rate for the study group was $>63 \%$. Further analyses showed that the P-gp positive expression rate in lung adenocarcinoma was significantly higher than that in lung squamous cell carcinoma. In clinical treatment, chemotherapeutic drug sensitivity of squamous cell carcinoma is higher than that of adenocarcinoma, which indirectly proves this conclusion (17). MDR1/P-gp is among the target genes of $\mathrm{HIF}-1 \alpha$. There is an HIF-1 binding site on the promoter region of MDR1/P-gp, therefore HIF-1 can induce the MDR1/P-gp expression and positively affect drug resistance. This observation has been confirmed through other studies (18). In vitro studies showed that the hypoxic microenvironment can increase the expression level of P-gp and HIF-1 $\alpha$ (19). Our results indicated that in the NSCLC patients with positive
HIF-1 $\alpha$ expression, the P-gp expression rate was significantly higher than that in the patients with negative HIF-1 $\alpha$ and we found a positive correlation between the two factors. It was also shown that HIF-1 $\alpha$ was involved in the occurrence and development of NSCLC and the drug resistance of tumor cells with P-gp by enhancing P-gp expression.

HPV infection mainly exists in cervical cancer, however, recent findings showed that lung cancer was closely linked to HPV infection (20-22). The HPV detection rate in the study group was significantly higher than the control group and the difference was statistically significant $(\mathrm{P}<0.05)$. A possible reason may be that HPV infection was one of the causes of NSCLC. The results indicated that HPV infection was closely related to the histological differentiation degree and lymph node metastasis. The detection rate of HPV DNA in the well-differentiated NSCLC was lower than that in the moderate and poorly differentiated samples. The reason may be explained by the fact that the differentiation maturation cells exit from the cell cycle and have no ability to divide, and only contain a small quantity of viral replication enzymes. The reason may be that HPV E6 plays a role in promoting VEGF expression and angiogenesis, inducing lymphangiogenesis and promoting metastasis similarly to the original oncogenes.

Wild-type p53 protein can reduce HIF-1 $\alpha$ activity through the direct inhibition of HIF-1 $\alpha$ transcription or promoting HIF-1 $\alpha$ ubiquitin-protease degradation mediated by MDM2. Previous findings (13) have shown that HPV 16 and 18 type E6 can promote the degradation of wild-type p53. However the results show that a positive expression rate of HIF-1 $\alpha$ in 
patients infected with HPV was higher than in those with no HPV infection. No significant difference was observed in the P-gp expression rates in patients with or without HPV infection, indicating the absence of any significant correlation between HPV infection and P-gp expression.

In conclustion, there was a close relationship between HIF-1 $\alpha$, P-gp and NSCLC occurrence, and development of MDR. In NSCLC, the detection of HIF-1 $\alpha$ and P-gp expression can effectively predict the possibility of drug resistance and can be used for evaluation of drug prognosis. HIF-1 $\alpha$ can be used as a tumor therapeutic target and blocking HIF-1 $\alpha$ can reduce tumor MDR and improve the survival rate.

\section{Acknowledgements}

The present study was funded by the Science and Technology Development Project of Suzhou City, Jiangsu Province (SYSD 2013162) and the Science and Technology Project of Jiangsu Health Department (YG201403).

\section{References}

1. Xie J, Liu J, Liu H, Liang S, Lin M, Gu Y, Liu T, Wang D, $\mathrm{Ge} \mathrm{H}$ and Mo SL: The antitumor effect of tanshinone IIA on anti-proliferation and decreasing VEGF/VEGFR2 expression on the human non-small cell lung cancer A549 cell line. Acta Pharm Sin B 5: 554-563, 2015.

2. Liang G-K, Yao Z-T, Zhang J-Q, Chen X, Liu R-Y, Chen H-H, Wu H-H, Jin L and Ding L: Statins enhance anti-tumor effect of suberoylanilide hydroxamic acid on human non-small cell lung carcinoma cells. Zhejiang Da Xue Xue Bao Yi Xue Ban 44: 500-505, 2015 (In Chinese).

3. Wei L, Li X and Yu Z: Mutations of EGFR gene and EML4-ALK fusion gene in superficial lymph node of non-small cel lung cancer. Zhonghua Yi Xue Za Zhi 95: 2070-2073, 2015 (In Chinese).

4. Fan H, Shao ZY, Xiao YY, Xie ZH, Chen W, Xie H, Qin GY and Zhao NQ: Incidence and survival of non-small cell lung cancer in Shanghai: a population-based cohort study. BMJ Open 5: e009419, 2015

5. Revannasiddaiah S, Joshi SC, Pandey KC, Rastogi M, Sharma M and Gupta M: The results with the addition of metronomic cyclophosphamide to palliative radiotherapy for the treatment of non-small cell lung carcinoma. Ann Transl Med 3: 305, 2015

6. Park SY, Yoon JK, Park KJ and Lee SJ: Prediction of occult lymph node metastasis using volume-based PET parameters in small-sized peripheral non-small cell lung cancer. Cancer Imaging 15: 21, 2015.

7. Zhao Q, Mao A, Yan J, Sun C, Di C, Zhou X, Li H, Guo R and Zhang H: Downregulation of Nrf2 promotes radiation-induced apoptosis through Nrf2 mediated Notch signaling in non-small cell lung cancer cells. Int J Oncol 48: 765-773, 2016.

8. Dai W, Luo B, Wu Z, Chen J, Feng G and Guan P: A multi-center phase II study of nintedanib as second-line therapy for patients with advanced non-small-cell lung cancer in China. Am J Cancer Res 5: 3270-3275, 2015.

9. Ma L, Wang R, Nan Y, Li W, Wang Q and Jin F: Phloretin exhibits an anticancer effect and enhances the anticancer ability of cisplatin on non-small cell lung cancer cell lines by regulating expression of apoptotic pathways and matrix metalloproteinases. Int J Oncol 48: 843-853, 2016
10. Paulsen EE, Kilvaer T, Khanehkenari MR, Maurseth RJ, Al-Saad S, Hald SM, Al-Shibli K, Andersen S, Richardsen E, Busund LT, et al: $\mathrm{CD} 45 \mathrm{RO}(+)$ memory $\mathrm{T}$ lymphocytes - a candidate marker for TNM-immunoscore in squamous non-small cell lung cancer. Neoplasia 17: 839-848, 2015.

11. Imai H, Kaira K, Mori K, Ono A, Akamatsu H, Matsumoto S, Taira T, Kenmotsu H, Harada H, Naito T, et al: Prognostic significance of diabetes mellitus in locally advanced non-small cell lung cancer. BMC Cancer 15: 989, 2015.

12. Cho HJ, Kim HR, Park YS, Kim YH, Kim DK and Park SI Prognostic value of survivin expression in stage III non-small cell lung cancer patients treated with platinum-based therapy. Surg Oncol 24: 329-334, 2015.

13. Chattopadhyay N, Berger AJ, Koenig E, Bannerman B, Garnsey J, Bernard H, Hales P, Maldonado Lopez A, Yang Y, Donelan J, et al: KRAS genotype correlates with proteasome inhibitor ixazomib activity in preclinical in vivo models of colon and non-small cell lung cancer: potential role of tumor metabolism. PLoS One 10: e0144825, 2015.

14. Horinouchi H, Goto Y, Kanda S, Fujiwara Y, Nokihara H, Yamamoto N, Sumi M, Tamura T and Ohe Y: Candidates for intensive local treatment in cIIIA-N2 non-small cell lung cancer: deciphering the heterogeneity. Int J Radiat Oncol Biol Phys 94: 155-162, 2016.

15. Deek MP, Benenati B, Kim S, Chen T, Ahmed I, Zou W, Aisner J and Jabbour SK: Thoracic vertebral body irradiation contributes to acute hematologic toxicity during chemoradiation therapy for non-small cell lung cancer. Int J Radiat Oncol Biol Phys 94: 147-154, 2016.

16. Vashi PG, Edwin P, Popiel B and Gupta D: The relationship between circulating 25-hydroxyvitamin $\mathrm{D}$ and survival in newly diagnosed advanced non-small-cell lung cancer. BMC Cancer 15: 1012, 2015.

17. Zhong S, Zhang H, Bai D, Gao D, Zheng J and Ding Y: Detection of ALK, ROS1 and RET fusion genes in non-small cell lung cancer patients and its clinicopathologic correlation. Zhonghua Bing Li Xue Za Zhi 44: 639-643, 2015 (In Chinese).

18. Mullins K: Stereotactic body radiotherapy for early-stage non-small cell lung cancer: when and why is it appropriate therapy? J Adv Pract Oncol 6: 351-354, 2015.

19. Li X, Qin N, Wang J, Yang X, Zhang X, Lv J, Wu Y, Zhang H, Nong J, Zhang Q, et al: Clinical observation of icotinib hydrochloride for advanced non-small cell lung cancer patients with EGFR status identified. Zhongguo Fei Ai Za Zhi 18: 734-739, 2015 (In Chinese).

20. Liang $\mathrm{H}$ and Wang $\mathrm{M}$ : Mechanism of c-MET in non-small cell lung cancer and its treatment and testing. Zhongguo Fei Ai Za Zhi 18: 745-751, 2015 (In Chinese)

21. Asamura H, Chansky K, Crowley J, Goldstraw P, Rusch VW, Vansteenkiste JF, Watanabe H, Wu YL, Zielinski M, Ball D, et al; International Association for the Study of Lung Cancer Staging and Prognostic Factors Committee, Advisory Board Members, and Participating Institutions: The International Association for the Study of Lung Cancer Lung Cancer Staging Project: proposals for the revision of the $\mathrm{N}$ descriptors in the forthcoming 8th edition of the TNM classification for lung cancer. J Thorac Oncol 10: 1675-1684, 2015.

22. Lee C, Usenko D, Frampton GM, McMahon C, Ali SM and Weiss J: MET 14 deletion in sarcomatoid non-small-cell lung cancer detected by next-generation sequencing and successfully treated with a MET inhibitor. J Thorac Oncol 10: e113-e114, 2015. 